\section{An Assessment of Oklahoma City Commercial Businesses' Willingness to Adopt Irrigation Water Conservation Methods}

\author{
Tracy A. Boyer ${ }^{1,3}$, D. Harshanee W. Jayasekera ${ }^{1}$, \\ and Justin Q. Moss ${ }^{2}$
}

ADDITIONAL INDEX wORDs. urban landscape, outdoor irrigation, commercial water conservation, willingness to pay

SUMMARY. Outdoor irrigation water conservation in the commercial sector has rarely been studied. Periodic drought stress in Oklahoma has forced utilities departments, including the City of Oklahoma City, to seek ways of conserving water in both the residential and nonresidential sectors. Most of these efforts largely targeted the residential sector. In this study, we determined the willingness of commercial businesses in the Oklahoma City metro area to participate in water conservation methods, such as installing soil moisture sensors (SMCs), installing smart irrigation controllers (SICs) for their businesses, and participating in voluntary landscape irrigation assessments (LIA). We conducted a mail survey of 3000 commercial customers in which we used contingent valuation (CV) questions to elicit the financial savings that would induce participation in an LIA or adoption of SIC $[n=381(13.7 \%$ response) $]$. A subsample experimental group received detailed information about future block rate water increases. Results of the study indicate that at current water utilities rates, commercial businesses are unlikely to adopt these conservation methods, but including information about future rate hikes may induce a subset of individuals to participate.

$\mathrm{W}$ orsening drought conditions alongside the growing demand for municipal water poses challenges in maintaining agricultural production, protection of natural water resources, and ensuring that urban areas have adequate water resources (Borisova et al., 2011). As a result, city governments have tried to manage urban demand for water by encouraging water-conserving behavior and technology adoption by municipal clients.

Oklahoma has experienced periodic droughts for the last decade, with historic and exceptionally extreme drought conditions in 2012 that forced city governments

\footnotetext{
This work was submitted as a part fulfilment of the requirements for the degree of Master of Science for Deshamithra Harshanee Wickramasinghe Jayasekera. This work was supported by the Oklahoma City Water Utilities Trust, the USDA National Institute of Food and Agriculture, Hatch project number OKL028252 and the National Science Foundation, EPSCOR award number IIA-1301789

${ }^{1}$ Department of Agricultural Economics, 321 Agriculture Hall, Oklahoma State University, Stillwater, OK 74078

${ }^{2}$ Department of Horticulture and Landscape Architecture, 358 Agriculture Hall, Oklahoma State University, Stillwater, OK 74078

${ }^{3}$ Corresponding author. E-mail: tracy.boyer@okstate. edu.
}

doi: 10.21273/HORTTECH03433-16 to prioritize water conservation (Arndt, 2002; South Central Climate Science Center, 2013). By Spring 2015 , conditions improved but still remained abnormally dry, and persistent areas of drought were projected in the Oklahoma Panhandle and southwestern Oklahoma (Heim, 2015)

Since the beginning of 2012 , the Oklahoma City Utilities Department (OKCUD) has actively sought ways to encourage its customers to conserve water. Mandatory water use restrictions in Oklahoma City include odd/even day watering and additional restrictions depending on the water levels of Oklahoma City's reservoirs (City of Oklahoma City, 2013). An inclining block rate pricing structure was implemented in Fall 2014 (Boyer et al., 2015; Crum, 2014). An inclining block rate pricing structure is designed to induce conservation of water by charging more per unit of water consumed above a given base block and may consist of two or more tiers of rates. Oklahoma City adopted an inclining block rate specifically to charge more to commercial and residential customers for increased summer use, primarily for irrigation. In Oklahoma City and elsewhere, education to encourage irrigation water conservation and water demand management has focused on the residential sector (Boyer et al., 2015; St. Hilaire et al., 2008), whereas outdoor irrigation water conservation in the nonresidential sector has largely been neglected (Renzetti, 2015; Worthington, 2010).

A number of studies have examined residential water conservation potential using price and nonprice water conservation policies. Price-based tools refer to pricing or incentive policies that potentially encourage conservation behavior, such as increasing water rates or subsidies like rebates (Adams et al., 2009; Ghimire et al., 2015). Nonprice mechanisms are regulatory approaches and educational measures such as water usage feedback and mandatory restrictions on watering. A large part of these conservation efforts promoted water-efficient appliances and feedback instruments (Boyer et al., 2015; Gracia-Valinas et al., 2015; Hayden et al., 2015; Lee et al., 2013; Makki et al., 2013; Woltemade and Fuellhart, 2013).

The way commercial customers' water consumption responds to price increases is termed as price elasticity of demand, i.e., how much water demand would change given an increase in price. Customers with higher elasticities of demand (i.e., elastic demands) are more likely to cut back on water use. According to Renzetti (2015) and Reynaud (2003), commercial water demand tends to be inelastic. However, demand elasticity for commercial water is slightly more elastic, i.e., more responsive, to price changes than the residential sector. For example, Renzetti (2015) found that elasticity estimates for the commercial sector in the United States ranged between -0.23 and -1.33 ; this means a $1 \%$ increase in price only lowered demand by $0.23 \%$. We expect that by

\begin{tabular}{llll}
\hline $\begin{array}{l}\text { Units } \\
\begin{array}{l}\text { To convert U.S. to SI, } \\
\text { multiply by }\end{array}\end{array}$ & U.S. unit & SI unit & $\begin{array}{l}\text { To convert SI to U.S., } \\
\text { multiply by }\end{array}$ \\
\hline 0.4047 & acre(s) & ha & 2.4711 \\
3.7854 & gal & L & 0.2642
\end{tabular}

Hortlechnology · December 2016 26(6) 
including information on future price increases, the likelihood of commercial customers of adopting an SMS, SIC, or LIA will be greater than for businesses that did not see that information.

Price and nonprice approaches for inducing water conservation have been widely applied by water managers with the belief that these will work for the commercial sector, but little research on the commercial sector exists (California Urban Water Conservation Council, 2016; U.S. Environmental Protection Agency, 2016; Water Services Association of Australia, 2009). Evidence for nonprice mechanisms shows that technological adoption can reduce consumption. Lee et al. (2013) found that the consumption of water was significantly reduced in households that installed high-efficiency appliances. Several studies also found that technological changes and innovations in irrigation systems could reduce the amount of water used in landscape irrigation (Haley et al., 2007; McCready et al., 2009). Other approaches such as irrigation audits or assessments are also discussed in literature for commercial clients (Austin Water, 2016; Dallas Water Utilities, 2016) and for households (McCue et al., 2007). McCue et al. (2007) observed that households that consumed more than $300 \mathrm{gal} /$ person per day were able to reduce their water use by $19 \%$ following an irrigation audit. A water demand management program in Sydney, Australia, in 1977, used many of the abovementioned conservation programs, including "industrial and commercial (water) audits" and "hotel (water) audits," among others. Results of the project indicated that residential clients were more receptive to these conservation programs than industrial clients and found that the industrial and hotel audits were not effective at reducing water use (White and Fane, 2007). Other technological studies in horticulture dealt with understanding the potential for conservation among different technological fixes such as rain sensors, SMS, and SIC (Grabow et al., 2013). In sum, commercial water customers have seldom been the research and policy target by decision-makers and they overall seem less responsive to price and nonpricing conservation programs than residential customers in outdoor water conservation.
The objective of this study is to use $\mathrm{CV}$, an economic study method that uses hypothetical scenarios about a change in costs, to analyze whether potential savings in water expenditures would induce commercial businesses to adopt outdoor irrigation water conservation methods and technologies. Second, the study examines the characteristics of firms that determine the likelihood of adopting water conservation methods. Finally, we tested whether including information on future price increases affects the likelihood of adoption.

\section{Materials and methods}

This study analyzed how commercial businesses responded to $\mathrm{CV}$ questions regarding water savings that could be gained by adopting outdoor irrigation water conservation methods and technologies. A CV question directly asks each respondent his or her willingness to accept a water conservation method at a randomly assigned monthly savings level given a hypothetical scenario (savings were given in U.S. dollars). Contingent valuation is usually used to estimate willingness to pay for ecosystem values and is called $\mathrm{CV}$ because average willingness-topay value estimated is contingent on the way the question is framed. We constructed hypothetical savings scenarios to quantitatively determine the savings level at which commercial businesses will install an SMS, install an SIC, and perform an LIA. For the purpose of this study, the conservation instruments were defined in the survey before viewing the $\mathrm{CV}$ as follows: an SMS is an instrument that measures the level of moisture in the soil, so the watering requirement can be determined; an SIC is an instrument that automatically adjusts irrigation run times in an irrigation system in response to weather conditions. SICs use sensor and weather information to manage watering times and frequency; and an LIA is conducted by a landscaping professional to identify ways to reduce the quantity of water used in irrigation, based on the watering needs of the landscape and plantings.

We also tested the likelihood of whether the inclusion of more information on current and future water prices would change the likelihood of commercial businesses adopting these conservation methods.
Data were collected via a mail survey of commercial customers of the OKCUD. The survey was administered in Fall 2015. The OKCUD provided a list of 16,287 commercial client addresses and actual water use data for each of these businesses for the months between Jan. 2011 and July 2015. After filtering for missing water consumption data and incomplete information, the survey was sent to 3000 randomly selected commercial businesses in the Oklahoma City metropolitan area using the "tailored design method" by Dillman et al. (2009). The survey was sent in two waves. First for a sample of 2000 businesses, and later to an additional sample of 1000 businesses as we observed a low response rate to the first wave of surveys. The first set of surveys in the initial wave was sent on 18 Sept. 2015. Following this, a postcard reminder was sent to nonresponses on 14 Oct. 2015. The postcard reminder gave the businesses the option of completing the survey online. On 6 Nov. 2015, the final set of surveys was sent to nonresponders in the initial wave. The second wave began on 12 Oct. 2015. We did not send businesses in the second wave a postcard reminder for the online option because we did not observe a significant difference in the response rate. Surveys for the nonresponders in the second wave were sent on 16 Nov. 2015. The survey of commercial businesses in Oklahoma City yielded 381 responses from 2784 deliverable addresses, resulting in a $13.7 \%$ response rate.

The survey consisted of three main sections: business demographics, CV questions, and respondent demographics. Surveys were tracked using a unique identification number that was later used to append the actual water consumption data. The three CV questions asked each respondent to indicate their willingness to adopt an SMS, to adopt an SIC, and to participate in an LIA.

Each of these CV questions, one scenario for each of the three methods, was printed with a randomly assigned monetary savings level, but the installation amount or cost of implementation did not vary within the question but varied by conservation method (Fig. 1). The cost of the LIA was zero. The cost of installation for the SMS and SIC was determined by the 
regional average cost for landscapers (J.Q. Moss, unpublished data). Therefore, each survey had a unique combination of monetary savings within the CV question, but within each method, the cost of adoption was constant.

The potential water savings were calculated based on actual water saving prospects for each conservation device. These savings ranged from $5 \%$ to $60 \%$ in $5 \%$ increments and were used in calculating 12 different potential savings levels in summer irrigation. These potential water savings were provided by the Department of Horticulture and Landscape Architecture of Oklahoma State University (J.Q. Moss, unpublished data). These savings amounts in the inclining block rate were converted into dollars using the inclining block rate for average monthly commercial summer irrigation for Oklahoma City at 12 potential levels that were randomly assigned to each respondent (\$50.67, \$101.34, \$152, \$202.67, \$253.34, \$304.01, \$354.68, \$405.34, $\$ 456.01, \$ 506.68, \quad \$ 557.35$, and \$608.02).

In Sept. 2014, the OKCUD introduced an inclining block rate water pricing structure, a change from a prior uniform volumetric water rate structure, for both residential and nonresidential utilities customers (City of Oklahoma City, 2014). As a result, commercial customers pay a higher cost for the volume of water they use

18. Smart irrigation controllers are devices that automatically adjust irrigation run times in response to changes in weather. They use sensors and weather information to manage watering times and frequency. The cost of a smart irrigation controller will be approximately $\$ 400$ a unit and the cost of labor would be approximately $\$ 90$ an hour. Would you consider installing a smart irrigation controller for your business's irrigation system, if it could save you \$354.68 for the months of June, July, and August each year?

$$
\square \text { Yes } \quad \square \text { No }
$$

Fig. 1. Example of a contingent valuation question for a smart irrigation controller presented in a survey of commercial businesses' willingness to participate in irrigation water conservation in Oklahoma City, OK, in a mail survey in 2015 designed to elicit willingness to adopt water conservation technologies.

above their winter averages. The OKWUD charges this higher rate in summer for the incremental use above the base winter average use to induce conservation in what is assumed to be more elastic summer irrigation demand (City of Oklahoma City, 2014). The sample population to whom the survey was sent was divided into two groups. Two-thirds of the sample received a complete table of information on how water rates in the inclining block rate structure would change in the future (Fig. 2), and one-third were randomly assigned to a control group that did not receive future price information.

OKCUD provided monthly water use data from Jan. 2011 to May 2015. Monthly data were used to obtain average estimates of irrigation water use for commercial businesses in Oklahoma City. Because separate irrigation water meters for many businesses are not available, the irrigation water use was calculated for all businesses by finding the difference between average summer monthly consumption (June, July, and August) and the average monthly winter water consumption (December, January, and February). The OKCUD uses average monthly winter water

The City of Oklahoma City moved to a "two-tier" water rate October 2014 to reflect increasing costs to supply water and to encourage conservation. As a result, businesses will experience a $15 \%$ higher cost for the volume of water they use above their average winter consumption. The second tier price per thousand gallons reflects the actual cost to customers of providing additional water when it is at peak demand in the summer.

Following is a table of OKC non-residential and irrigation water rates [US $\$$ per 1000 gallons]

\begin{tabular}{|l|l|l|l|}
\hline Tier & Until Sep. 30 2015 & Oct. 1 2015 - Sep. 30 2016 & After Oct. 1 2016 \\
\hline Tier 1 & $\$ 2.71$ & $\$ 2.76$ & $\$ 2.81$ \\
\hline Tier 2 & $\$ 3.12$ & $\$ 3.26$ & $\$ 3.40$ \\
\hline
\end{tabular}

Tier 2 is paid per 1000 gallons of water used by the individual businesses above its own average winter water use (From December to February).

Fig. 2. Additional information on how water utilities rates would increase in the future provided to an experimental group in a mail survey in 2015 to analyze commercial businesses' willingness to participate in irrigation water conservation in Oklahoma City, OK $(\mathrm{OKC})$, given information on future rates, OKC; 1 gal = 3.7854 L, \$1/gal = \$0.2642/L. 
consumption to serve as the base rate (Ghimire et al., 2015). In some cases, these irrigation water consumption estimates may be overestimated because some seasonal businesses such as water parks use water only in the summer. To avoid this overestimation, any businesses with zero water usage records in the winter season were removed from the survey sample. A similar method was used by Hermitte and Mace (2012) where they assumed the lowest water usage in a given calendar year to be the best estimate of indoor water consumption from a series of data pertaining to residential water usage in Texas, and they counted any additional water utility use as outdoor consumption. However, this method may overestimate indoor water use and may underestimate outdoor water use (Hermitte and Mace, 2012). Data from the survey and the monthly water consumption were joined for this analysis.

Stated preference methods such as conjoint choice and $\mathrm{CV}$ are often used as the methodological approach for quantifying consumer choice for goods or environmental preferences (Lusk, 2011; Yue and Tong, 2011). In this study, a CV method is used to pose a hypothetical cost-saving scenario to commercial water customers. A CV question asks respondents if they would accept or reject a scenario presented in the question if they have to pay or if they would be compensated using a given dollar amount (Blaine and Smith, 2006; King and Mazzotta, 2000; Koss and Khawaja, 2001). We assume that the business maximizes utility by choosing one alternative over the other. The utility, $U_{i j}$, of the $i^{\text {th }}$ business choosing the $j^{\text {th }}$ alternative can be written as (Haab and McConnell, 2003):

$$
U_{i j}=\beta X_{i j}+\varepsilon_{i j}
$$

where $\beta X_{i j}$ represents the deterministic part of the utility or the observable utility of the $i^{\text {th }}$ individual choosing $j^{\text {th }}$ alternative and $\varepsilon_{i j}$ represents the random or unobservable utility. In the observable utility portion, $X_{i j}$ indicates the dollar amounts businesses would save every summer and all other individualand firm-specific characteristics. The corresponding parameter estimates are represented by $\beta$. Because the responses to the $\mathrm{CV}$ questions are binary, $j$ can only take two values: $j=1$ or 0 .

The logistic model is used to test the likelihood of businesses adopting or not adopting the SMS, SIC, or LIA. We can express the deterministic part of the utility $V_{i j}=\beta X_{i j}$ as introduced in Eq. [1] and can be further elaborated as follows:

$$
\begin{aligned}
V_{i j}= & \beta_{0}+\beta \text { Savings }_{i j}+\beta \text { Control }_{i j} \\
& +\beta \text { Adoption }_{i j} \\
& +\beta{\text { Landscaped } \text { acreage }_{i j}} \\
& +\beta \text { Industry }_{\text {officeij }_{i j}} \\
& +\beta \text { Industry }_{\text {food }_{i j}} \\
& +\beta \text { Industry }_{\text {helthcare }_{i j}} \\
& +\beta \text { Industry }_{\text {construction }_{i j}} \\
& +\beta \text { Industry }_{\text {other }_{i j}} \\
& +\beta \text { College }_{i j} \\
& +\beta \text { Graduate }_{i j} \\
& +\beta \text { Incomel }_{i j} \\
& +\beta \text { Income }_{i j} \\
& +\beta{\text { Years in } \text { business }_{i j}} \\
& +\beta \text { Years at location }_{i j} \\
& +\beta \text { No. employees }_{i j} \\
& +\beta \text { Drought perceptions }_{i j} \\
& +\beta \text { Irrigation source }_{i j} \\
& +\beta \text { Appearence_most }_{i j} \\
& +\beta \text { Efficiency_most }_{i j} \\
& +\beta \text { Irrigation audit }_{i j} \\
& +\beta \text { Free education }_{i j} \\
& +\beta \text { Female }_{i j} \\
& +\beta{\text { Decision } \text { maker }_{i j}} \\
& +\beta \text { Age }_{i j}+\beta \text { Summerl }_{i j} \\
& +\beta \text { Summerl }_{i j} \\
& +\beta \text { Summerl4 }_{i j} \\
&
\end{aligned}
$$

Table 1 provides descriptions of the variables in Eq. [2]. Endogeneity between water conservation and drought perceptions and acceptance of the bid was ruled out by determining that the error terms were not correlated with these variables. At the outset of the survey, we requested that the survey recipients make sure the decision-makers for the landscaping complete the surveys. This distinction was important to assure familiarity with the landscaping options and to reduce hypothetical bias by surveying actual decision-makers familiar with the landscaping budget.
The logistic regression shown in Eq. [2] and the log-odds ratios were estimated using Stata (release 13; StataCorp, College Station, TX). Post estimation of the logistic regression, odds ratios were calculated so the likelihood of adoption of any one of the conservation methods discussed in this study can be easily understood.

\section{Results}

Ninety-nine percent of the businesses that responded to the survey had been in business for longer than 5 years, and $97 \%$ were at their current location in Oklahoma City for more than 5 years. This indicates that when the drought was in its peak in 2012, these firms were in business and may have experienced the supply shortage and water pressure problems in Oklahoma City during the drought. Because $84 \%$ of the businesses depend primarily on city water utilities for their irrigation supply, we postulate that OKCUD has significant market power in nudging businesses toward conservation, but, as the results indicate, not at current prices and estimated conservation savings.

The survey solicited information about the area of landscape maintained. Because larger landscapes need more irrigation, water savings were more likely to be attractive for businesses with larger landscaped areas. More than $90 \%$ of businesses in the sample had less than 1 acre of landscaping to maintain. We wanted to test attitudinal effects on adoption by the commercial sector because in the residential sector, perception and attitudes of homeowners significantly affect conservation adoption (Boyer et al., 2015; Domene and Saurai, 2006). Sixty-four percent of respondents indicated that appearance of the landscape is the most important attribute, whereas only $2 \%$ of the responding businesses indicated that water efficiency is the most important attribute. In addition, we asked respondents to indicate their perceptions on the likelihood of Oklahoma going into another drought within the next 3 years. Close to $70 \%$ of the respondents thought that it is very likely or somewhat likely, while $22 \%$ were unsure; $6 \%$ and $3 \%$ percent of the respondents thought it was somewhat unlikely or not likely at all, respectively. 


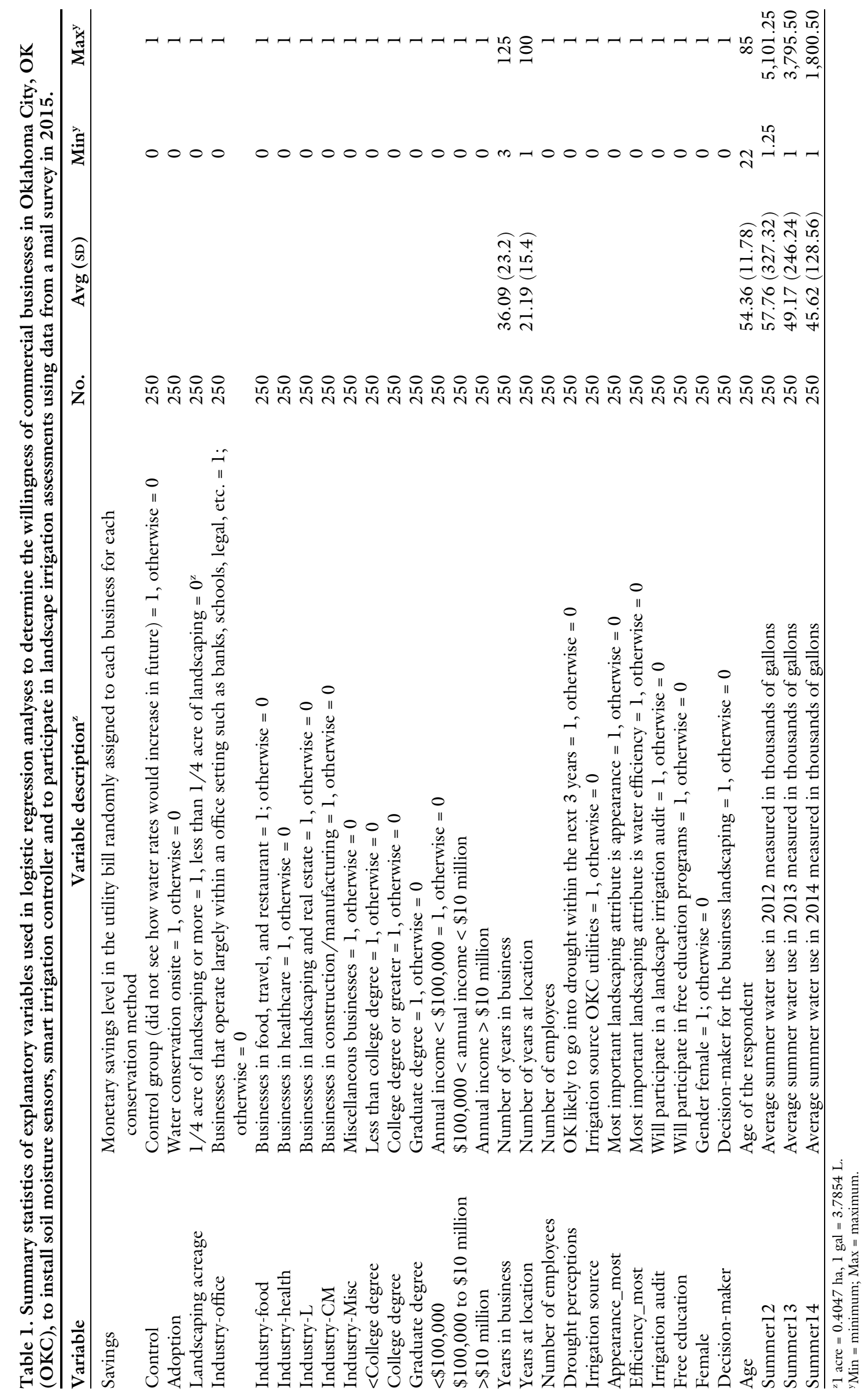


The average age of the respondents was 54 years, and the majority of the respondents were male (Summary statistics of the demographics of individual respondents are reported in Table 2.). Sample respondents were also highly educated with more than $50 \%$ having at least a college degree.

In prelogistic estimation, we tested three logistic models of willingness to adopt the SMS, SIC, and LIA given the randomly assigned bids (Stata release 13). Independent variables used in the logistic regressions and their summary statistics are shown in Table 1. In postlogistic estimation, we tested for overall model significance using a likelihood ratio (LR) test. The SMS model did not significantly explain the determinants of adoption, thus the estimation is not included and only the results for the other two models are reported (Table 4). Results of the LR test are reported in Table 3 . For this LR test, the null hypothesis is $\mathrm{H}_{0}$ : all coefficients are equal to zero; i.e., the variables in the model are not good predictors of the willingness of commercial businesses to install an SMS, or SIC, or participate in an LIA. With the probabilities associated with the LR test less than the critical value $(P \leq$ 0.05 ), we could reject the null hypothesis for the logistic models estimated for SIC and LIA. We conclude the SIC and LIA models explain potential adoption behavior. For the SMS model, because the probability associated with the LR test is greater than the critical value of $P \leq$ 0.05 , we could not reject the null hypothesis that the coefficients of the determinants were equal to zero and we excluded this model from further analysis. This means neither the potential savings, nor the other firm characteristics, significantly affect the probability of adopting an SMS. Table 4 reports the logistic models for SIC and LIA and their robust standard errors. Robust standard errors correct for unequal variances in residuals that affect the standard errors of the coefficient and subsequent inferences derived using these incorrect standard errors. The odds ratios for the logistic equations report the odds of a respondent accepting the savings amounts over the odds of a respondent rejecting the savings amount presented in the $\mathrm{CV}$ questions in installing an SIC or participating in an LIA (Table 5 ).

Model 1: Willingness to InSTALL AN SIC. In Model 1, the coefficient for "savings" was not statistically significant. The lack of significance of the "savings" coefficient means that the savings bids viewed by respondents on average were not high enough to affect their likelihood of saying yes to the $\mathrm{CV}$ scenario. The lack of significance of this coefficient

Table 2. Summary statistics of persons that responded to a survey of commercial businesses' willingness to participate in irrigation water conservation in Oklahoma City, OK.

\begin{tabular}{|c|c|c|c|c|}
\hline Demographic attribute $^{\mathrm{z}}$ & Frequency & Share $(\%)$ & $\operatorname{Min}^{\mathrm{y}}$ & $\operatorname{Max}^{\mathrm{y}}$ \\
\hline \multicolumn{5}{|l|}{ Gender $(n=229)$} \\
\hline Male & 147 & 64.19 & 0 & 1 \\
\hline Female & 82 & 35.81 & 0 & 1 \\
\hline \multicolumn{5}{|l|}{ Education $(\mathrm{n}=230)$} \\
\hline High-school diploma & 13 & 5.65 & 0 & 1 \\
\hline Some college & 56 & 24.35 & 0 & 1 \\
\hline College graduate & 99 & 43.04 & 0 & 1 \\
\hline Some graduate & 10 & 4.35 & 0 & 1 \\
\hline Graduate degree & 52 & 22.61 & 0 & 1 \\
\hline \multicolumn{5}{|c|}{ Decision-maker for the firm $(\mathrm{n}=227)$} \\
\hline Yes & 197 & 86.78 & 0 & 1 \\
\hline No & 30 & 13.21 & 0 & 1 \\
\hline \multicolumn{5}{|c|}{ Ownership of the business $(n=232)$} \\
\hline Owner & 139 & 59.91 & 0 & 1 \\
\hline Otherwise & 93 & 40.09 & 0 & 1 \\
\hline Age $(\mathrm{n}=230)^{\mathrm{x}}$ & & & 22 & 85 \\
\hline
\end{tabular}

${ }^{\mathrm{z}} \mathrm{n}=$ number of observations in the category total

${ }^{\mathrm{y}} \mathrm{Min}=$ minimum; Max $=$ maximum.

${ }^{\mathrm{x}}$ Mean age was 54 years, sD was 12 years. means that we cannot calculate the savings level at which an average commercial business would be persuaded to actually adopt an SIC. However, other variables were significant and can provide insight into business firm behavior. The control group that did not see additional information on water rate changes in the future, indicated by the variable "control," was statistically significantly less likely to adopt an SIC at $95 \%$ level of confidence. For each business that installs an SIC in the noncontrol group, the odds of installing an SIC in the control group was 3 in 10. "Adoption" indicated businesses that have already taken steps to conserve water and was statistically significant at $95 \%$ level of confidence. The associated odds ratio suggested that this group was close to seven times more likely to install an SIC for their businesses than those who had not taken steps to conserve water on site.

Businesses that maintained a $1 / 4$ acre or more of land were also more likely to adopt an SIC compared with businesses with less than $1 / 4$ acre of landscaping at $99 \%$ level of confidence. The odds of installing an SIC was four times more for businesses with $1 / 4$ acre or more of landscaping than otherwise. "Food," "healthcare," and "other" industry (most commonly a church or oil and gas operation) categories were significantly less willing to install SICs for their businesses, compared with respondents in the "home and landscape" industry category. These coefficients were significant at $90 \%$ level of confidence. The odds of installing an SIC for the "food," "healthcare," and "other" industry categories, respectively, were 1 in 100,20 in 100 , and 8 in 100 . With a negative and significant coefficient for "years at location," indicates that with each additional year that a business has been located in Oklahoma City, it is less likely to install an SIC. The odds ratio of installing an SIC was 0.95 for each additional "year at location" and is significant at $95 \%$ level of confidence. The variable "number of employees" was used as a proxy for the size of the business. This variable was positive and significant at $95 \%$ level of confidence, suggesting that larger businesses are more likely to install SICs. "Summer14" 
Table 3. Likelihood ratio (LR) test for the logistic regression models estimated to determine willingness to install soil moisture sensors (SMS), smart irrigation controllers (SIC) and to participate in landscape irrigation assessments (LIA) of firms responding to a survey of commercial businesses' willingness to participate in irrigation water conservation in Oklahoma City, OK.

\begin{tabular}{|c|c|c|c|}
\hline Model description & Model 1: SMS & Model 2: SIC & Model 3: LIA \\
\hline LR chi-square test statistic & 9.96 & $113.05^{* * *}$ & $70.23^{* * *}$ \\
\hline Probability associated with the LR test statistic & 0.13 & 0.00 & 0.00 \\
\hline Degrees of freedom used for the calculation of the LR chi-square test statistic & 6 & 28 & 27 \\
\hline
\end{tabular}

$* * *,{ }^{* *},{ }^{*}$ indicate statistical confidence at $99 \%, 95 \%$, and $90 \%$, respectively.

Table 4. Logistic regression results estimated to determine willingness to install smart irrigation controllers (SIC) and to participate in landscape irrigation assessments (LIA) of firms responding to a survey of commercial businesses' willingness to participate in irrigation water conservation in Oklahoma City, OK, collected by mail survey in 2015.

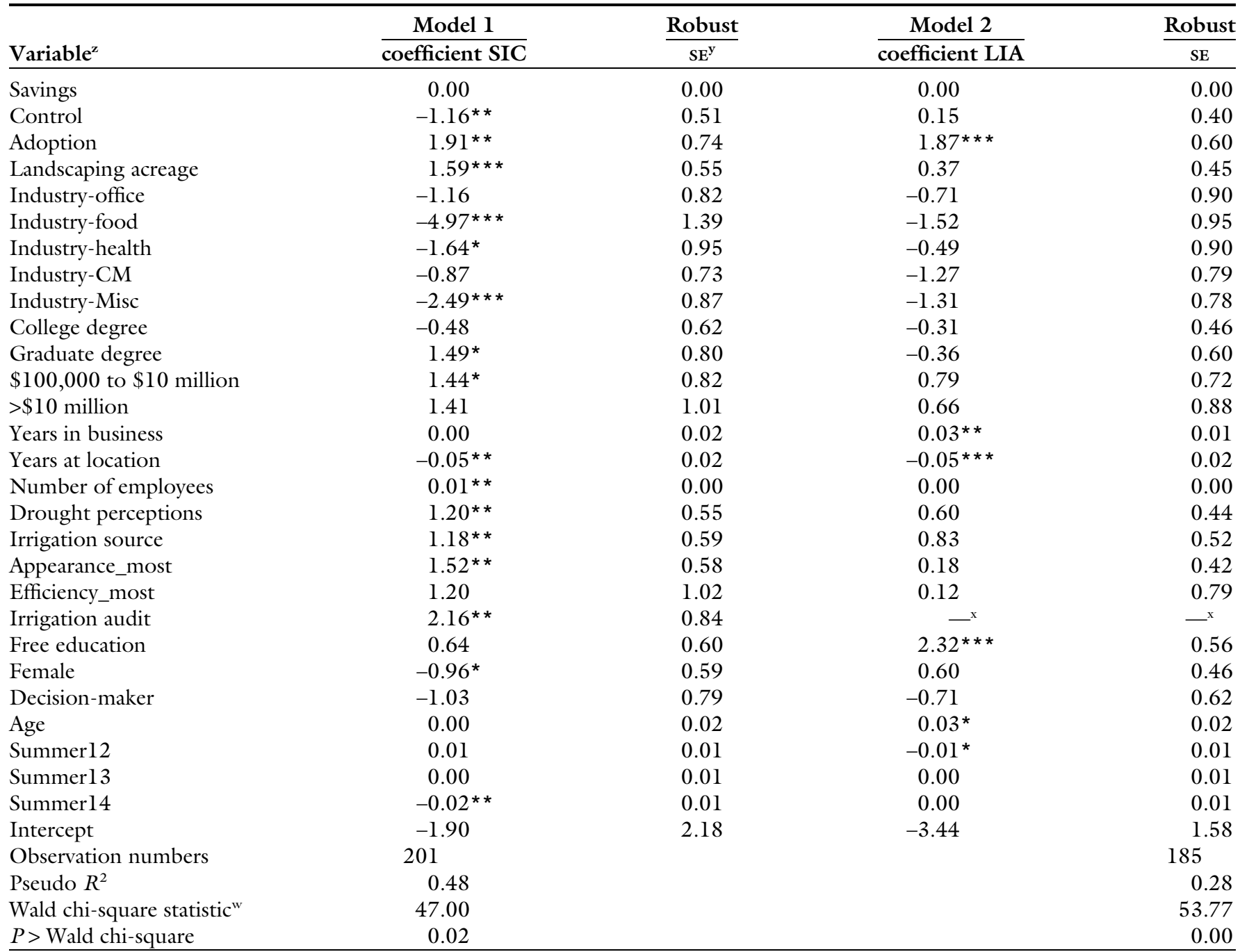

${ }^{2}$ Definitions of variables are provided (Table 1 ).

'Robust SE are corrected for unequal variances in the error residuals.

'Indicates that a variable was omitted by the statistical package due to lack of variation within groups.

"Wald chi-square tests if the overall model is statistically significant.

$* * *,{ }^{* *}, *$ indicate statistical confidence at $P \leq 0.01,0.05$, and 0.01 , respectively.

actual water usage series was negative and significant at $95 \%$ level of confidence in the SIC model indicating that higher users of water in 2014, still a drought year, were less likely to install an SIC.
Respondent characteristics applicable to Model 1 indicated that persons with graduate degrees were significantly more likely to be willing to install an SIC for their business at $90 \%$ level of confidence compared with those with less than a college degree. A graduate degree increased the odds of installing an SIC by more than four times. Female respondents were less likely to be willing to install an SIC for the business compared 
Table 5. Odds ratio calculations derived for the logistic regression results estimated to determine the willingness to install smart irrigation controllers (SIC) and to participate in landscape irrigation assessments (LIA) of firms responding to a survey of commercial businesses' willingness to participate in irrigation water conservation in Oklahoma City, OK, collected by mail survey in 2015.

\begin{tabular}{|c|c|c|c|c|}
\hline Variable $^{\mathrm{z}}$ & $\frac{\text { Model } 1 \text { (SIC) }}{\text { Odds ratio }}$ & $\frac{\text { Robust }}{\mathrm{SE}^{\mathrm{y}}}$ & $\frac{\text { Model } 2 \text { (LIA) }}{\text { Odds ratio }}$ & $\frac{\text { Robust }}{\text { SE }}$ \\
\hline Savings & 1.00 & 0.00 & 1.00 & 0.00 \\
\hline Adoption & $6.76^{* *}$ & 4.98 & $6.47 * * *$ & 3.90 \\
\hline Landscaping acreage & $4.93 * * *$ & 2.69 & 1.44 & 0.64 \\
\hline Industry-office & 0.31 & 0.26 & 0.49 & 0.44 \\
\hline Industry-CM & 0.42 & 0.31 & 0.28 & 0.22 \\
\hline Industry-misc & $0.08 * * *$ & 0.07 & $0.27^{*}$ & 0.21 \\
\hline College degree & 0.62 & 0.39 & 0.74 & 0.34 \\
\hline Graduate degree & $4.44^{*}$ & 3.55 & 0.70 & 0.42 \\
\hline$\$ 100,000$ to $\$ 10$ million & $4.22 *$ & 3.46 & 2.20 & 1.58 \\
\hline Drought perceptions & $3.32 * *$ & 1.82 & 1.82 & 0.81 \\
\hline Irrigation source & $3.25^{*}$ & 1.92 & 2.29 & 1.20 \\
\hline Appearance_most & $4.55^{* *}$ & 2.64 & 1.20 & 0.50 \\
\hline Efficiency_most & 3.33 & 3.40 & 1.13 & 0.89 \\
\hline Irrigation audit & $8.67 * *$ & 7.27 & $-^{x}$ & $-^{x}$ \\
\hline Free education & 1.90 & 1.14 & $10.16^{* * *}$ & 5.69 \\
\hline Female & $0.38^{*}$ & 0.23 & 1.83 & 0.84 \\
\hline Decision-maker & 0.36 & 0.28 & 0.49 & 0.31 \\
\hline Age & 1.00 & 0.02 & $1.03^{*}$ & 0.02 \\
\hline Summerl2 & 1.01 & 0.01 & $0.99 *$ & 0.01 \\
\hline Summerl3 & 1.00 & 0.01 & 1.00 & 0.01 \\
\hline
\end{tabular}

${ }^{2}$ Definitions of variables are provided (Table 1 ).

' Robust SE are calculated standard errors that are corrected for unequal variances in the error residuals.

${ }^{x}$ Indicates that a variable was omitted by the statistical package due to lack of variation within groups when the logistic model was estimated (Table 4 ).

$* * *, * *, *$ indicate statistical confidence at $99 \%, 95 \%$, and $90 \%$, respectively.

with males and was statistically significant with a $90 \%$ level of confidence $(P \leq 10 \%)$. The odds of a female respondent installing an SIC was 4 in 10 ; i.e., they were $60 \%$ less likely than men to install an SIC. By contrast, in a study of the residential sector in in Oklahoma City, OK, the household decision-maker's gender did not significantly affect the likelihood of water conservation technology adoption (Boyer et al., 2015).

Model 2: Willingness to PARTICIPATE IN AN LIA. In Model 2, the variable "savings" was not statistically significant and prevented us from calculating the savings level at which businesses would make a shift toward conducting an LIA. However, a number of other variables were significant in the model that can provide insight into firm behavior.
"Adoption" was statistically significant at $99 \%$ level of confidence $(P \leq$ 0.01 ) and indicated that business that have already taken steps to conserve water compared with those businesses that did not, were more likely to conduct an LIA, where the odds of participating in an LIA was six times greater. The variable "years in business" was positive and significant at 95\% level of confidence indicating that older businesses were more likely to conduct an LIA. However, "years at location" variable was negative and significant at $99 \%$ level of confidence, and indicated that businesses located in Oklahoma City for longer were less likely to conduct LIAs. "Free education" was positive and significant at $99 \%$ level of confidence suggesting that businesses who indicated their willingness to participate in free education programs on water conservation conducted by the OKCUD were more likely to conduct an LIA for their business. The corresponding odds ratio indicated that among those who would participate in free educational programs, the odds of conducting an LIA was 10 times higher than those who did not choose to participate.

\section{Discussion}

The objective of this study was to identify savings levels at which commercial businesses would increase their water conservation by installing SMSs, SICs, and conducting landscape irrigation audits to identify areas of overuse. The lack of statistical significance of the variable "savings" indicated that the range of monthly water bill savings at current water 
utility rates were insufficient to induce these businesses to install an SIC or participate in an LIA. Because current water rates are not high enough per $1000 \mathrm{gal}$ for these businesses to be concerned, the savings levels calculated using these low water prices are insufficient to encourage conservation. Nonetheless, this study found evidence to suggest that the prospect of water being more expensive in the future could make statistically significant differences in firms' adoption decisions for landscape irrigation audits and SICs. As discussed previously, the SMS questions were not statistically significant and were dropped from discussion. The lack of significance for the SMS is likely because the subsample that did not already have a soil moisture sensor was smaller and if they were to adopt a new technology, they would be more likely to skip an SMS for an SIC system. Therefore, we believe that already slated yearly rate increases by the OKCUD may eventually persuade commercial businesses to pay more attention to conserving water onsite. Furthermore, rebates for professionally installed SICs would result in a shorter payback time for SIC in terms of savings to the firm. If the water utility is forced to add supply or larger pipeline capacity city wide to meet summer irrigation demand, rebates sufficient to induce SIC adoption that are less (a benefit) than the cost of new pipelines make sense in benefit-cost terms.

Among other important aspects, the analysis in this study found evidence to suggest the need for better targeting of water conservation policies at the individual company level. Targeting businesses on both ends of the acreage spectrum is most likely to yield results. With a majority of firms in the sample maintaining less than $1 / 4$ acre of land and these firms being less likely to install SICs, policymakers should target these firms' irrigation water demand management efforts as their cumulative summer consumption is important, particularly for decreasing water pressure problems during drought. Additional research is needed to understand why older businesses are less likely to install SICs for their businesses and are less likely to participate in LIAs. In the residential sector, residents in old buildings are less likely to adopt conservation tools because their infrastructure does not allow large-scale physical changes (Boyer et al., 2015). If this true for the nonresidential sector as well, utilities departments could target their efforts toward newer businesses using a combination of educational programs, rebates, and mandatory landscape codes. Decision-makers with graduate degrees were more likely to adopt irrigation controllers, thus information about payback rates and efficacy should be aimed toward less educated decision-makers. New firms and firms with more acreage to irrigate are more likely to adopt new technologies when first installing irrigation systems and new installations are likely to be cheaper than retrofitting old irrigation systems. Perception that "drought is likely" increases the likelihood of adoption of SICs. Education and community outreach to explain the cyclical nature of drought may increase conservation method adoption by commercial decision-makers. Furthermore, because firms ranked landscape appearance first and the relative savings of water last in importance shows that the OKCUD must work to combat the perception that water conservation will result in unattractive landscapes. One avenue for future research would be to examine whether decreases in costs in addition to water savings might be the nudge that induces firms to adopt smart controllers and irrigation assessments.

\section{Literature cited}

Adams, D.C., C.N. Boyer, and M.D. Smolen. 2009. Water rate structure: A tool for water conservation in Oklahoma. 25 July 2016 . <http://pods.dasnr. okstate.edu/docushare/dsweb/Get/ Rendition-11238/AGEC-1017web. pdf>.

Arndt, D.S. 2002. The Oklahoma drought of 2001-2002. 30 Sept. 2016. <http://climate.ok.gov/summaries / event/Drought_of_2001-2002.pdf>.

Austin Water. 2016. ICI audit rebate. 1 Feb. 2016. <https://www.austintexas. gov/page/ici-audit-rebate $>$.

Blaine, T.W. and T. Smith. 2006. From water quality to riparian corridors: Assessing willingness to pay for conservation easements using the contingent valuation method. J. Ext. 44(2):2FEA7. 18 Oct. 2016 . <https://joe.org/joe/ 2006april/a7.php>.
Borisova, T., C. Rawls, and D. Adams. 2011. Balancing urban water demand in Florida: Overview of tools available to water managers. 5 May 2015. <http:// edis.ifas.ufl.edu/fe811>.

Boyer, T.A., P. Kanza, M. Ghimire, and J.Q. Moss. 2015. Household adoption of water conservation and resilience under drought: The case of Oklahoma City. Water Econ. Policy 1(2):1-21.

California Urban Water Conservation Council. 2016. Smart rebates program. 1 Feb. 2016. <https://www.cuwcc.org/ Resources/Conservation-at-Home-andWork/Smart-Rebates-Program $>$.

City of Oklahoma City. 2013. Water conservation. 31 Jan. 2016. <https:// www.okc.gov/departments/utilities / squeeze-every-drop/water-conservation$\operatorname{program} />$.

City of Oklahoma City. 2014. OKC water and wastewater rates and fees. 8 Jan. 2016. <https://www.okc.gov/ departments/utilities/customer-service/ rates-fees\#OKC Residential Customers>.

Crum, W. 2014. Oklahoma City water rate increases take shape. 28 Jan. 2016. $<$ http://newsok.com/article/ $4879991>$.

Dallas Water Utilities. 2016. Save water: Rebates and incentives. 1 Feb. 2016. <https://savedallaswater.com/rebatesand-incentives $/>$.

Dillman, D.A., J.D. Smyth, and L.M. Christian. 2009. Internet, mail, and mixed-mode surveys: The tailored design method. 3rd ed. Wiley, Hoboken, NJ.

Domene, E. and D. Saurai. 2006. Urbanization and water consumption: Influencing factors in the metropolitan region of Barcelona. Urban Stud. 43:16051623.

Ghimire, M., T.A. Boyer, C. Chung, and J.Q. Moss. 2015. Estimation of residential water demand under uniform volumetric water pricing. J. Water Resour. Plan. Mgt. 142:1943-5452.

Grabow, G.L., I.E. Ghali, R.L. Huffman, G.L. Miller, D. Bowman, and A. Vasanth. 2013. Water application efficiency and adequacy of ET-based and soil moisture based irrigation controllers for turfgrass irrigation. J. Irr. Drain. Eng. 139:113123.

Gracia-Valinas, M.A., R. Martinez-Espineira, and H. To. 2015. The use of non-pricing instruments to manage residential water demand: What have we learned? p. 269282. In: K.A. Daniell, J.D. Rinaudo, N.W.W. Chan, C. Nauges, and Q. Grafton (eds.). Understanding and managing urban 
water in transition. Springer, Dordrecht, The Netherlands.

Haab, T.C. and K.E. McConnell. 2003. Site choice models, p. 190-244. In: Valuing environmental and natural resources. The economics of non-market valuation. Edward Elgar, Northampton, PA.

Haley, M.B., M.D. Dukes, and G.L. Miller. 2007. Residential irrigation water use in central Florida. J. Irr. Drain. Eng. 133:427-434.

Hayden, L., M.L. Cadenasso, D. Haver, and L. Oki. 2015. Residential landscape aesthetics and water conservation best management practices: Homeowner perceptions and preferences. Landsc. Urban Plan. 144:1-9.

Heim, R. 2015. U.S. drought monitor. 17 Feb. 2015. <http://droughtmonitor. unl.edu/>.

Hermitte, S.M. and R.E. Mace. 2012. The grass is always greener: Outdoor residential water use in Texas. Texas $\mathrm{Wa}$ ter Dev. Board Tech. Note 12 (1). 30 Sept. 2016. <http://www.twdb.texas. gov/publications/reports/technical_ notes/doc/SeasonalWaterUseReportfinal.pdf>.

King, M.D. and M.J. Mazzotta. 2000. Contingent valuation method. 9 Mar. 2016. <http://www.ecosystemvaluation. org/contingent_valuation.htm>.

Koss, P. and M.S. Khawaja. 2001. The value of water supply reliability in California: A contingent valuation study. Water Policy 3:165-174.

Lee, M., B. Tansel, and M. Balbin. 2013. Urban sustainability incentives for residential water conservation: Adoption of multiple high efficiency appliances. Water Resour. Mgt. 27:2531-2540.

Lusk, J.L. 2011. Consumer preferences for genetically modified food, p. 243259. In: C.A. Carter, G. Moschini, and I. Sheldon (eds.). Frontiers of economics and globalization. Emerald Group, Bingley, UK.

Makki, A.A., R.A. Stewart, K. Panuwatwanich, and C. Beal. 2013. Revealing the determinants of shower water end use consumption: Enabling better targeted urban water conservation strategies. J. Clean. Prod. 60:129-146.

McCready, M.S., M.D. Dukes, and G.L. Miller. 2009. Water conservation potential of smart irrigation controllers on st. augustinegrass. Agr. Water Mgt. 96(11):16231632 .

McCue, T., J. Murin, and D. Meinert. 2007. Quantifying potable water savings derived from a residential irrigation audit program in Seminole County. Florida, Water Resour. J. 2007:52-54.

Renzetti, S. 2015. Non-household water demand: The industrial and commercial sectors, p. 297-310. In: K.A. Daniell, J.D. Rinaudo, N.W.W. Chan, C. Nauges, and Q. Grafton. (eds.). Understanding and managing urban water in transition. Springer, Dordrecht, The Netherlands.

Reynaud, A. 2003. An econometric estimation of industrial water demand in France. Environ. Resour. Econ. 25:213232.

South Central Climate Science Center. 2013. Drought history for central Oklahoma. I Feb. 2016. <http://www. southcentralclimate.org/content/ documents/factsheets/Drought_History_ OKCD05.pdf $>$.
St. Hilaire, R., M.A. Arnold, D.C. Wilkerson, D.A. Devitt, B.H. Hurd, B.J. Lesikar, V. I. Lohr, C.A. Martin, G.V. McDonald, R.L. Morris, D.R. Pittenger, D.A. Shaw, and D.F. Zoldoske. 2008. Efficient water use in residential urban landscapes. HortScience 43:2081-2092.

U.S. Environmental Protection Agency. 2016. Rebate finder. I Feb. 2016. <http://www3.epa.gov/watersense/ rebate_finder_saving_money_water. html>.

Water Services Association of Australia. 2009. Meeting Australia's water challenges: Case studies in commercial and industrial water savings. WSAA Occasional Paper No. 23. Water Serv. Assn. Australia, Melbourne, Australia.

White, S.B. and S.A. Fane. 2007. Designing cost effective water demand management programs in Australia. Water Sci. Technol. 46(6-7):225-232.

Woltemade, C. and K. Fuellhart. 2013. Economic efficiency of residential water conservation programs in a Pennsylvania public water utility. Prof. Geogr. 65 (1):116-129.

Worthington, A.C. 2010. Commercial and industrial water demand estimation: Theoretical and methodological guidelines for applied economics research. 1 Feb. 2016. <https://www.griffith.edu. au/_data/assets/pdf_file/0019/ $261154 / 2010$ - 11 - commercial and-industrial-water-demand-estimationtheoretical-and-methodological-guidelinesfor-applied-economics-research.pdf $>$.

Yue, C. and C. Tong. 2011. Consumer preferences and willingness to pay for existing and new apple varieties: Evidence from apple tasting choice experiment. HortTechnology 21(3):376383. 